\title{
The Positive Effects of Task, Relation and Change Oriented Leadership Behavior on Employee Engagement
}

\author{
Yong Li \\ Lawrence Technological University \\ Patricia A. Castelli \\ Lawrence Technological University \\ Matthew Cole \\ Lawrence Technological University
}

\begin{abstract}
This research examined the relationship between task, relation-oriented, and change-oriented leadership behavior on employee engagement. This study employed a quantitative design and collected data from 117 participants in 13 countries through an online survey. Employee engagement and leadership behavior were evaluated using Cronbach's coefficient alpha, confirmatory factor analysis (CFA), and regression analyses. Results suggest that all three types of leadership behavior (task, relation, and change-oriented) have positive impact on employee engagement with change being the highest, and that the impact of leadership behavior on employee engagement is moderated by employee age and management status. Strategies for improving employee engagement are presented.
\end{abstract}

Keywords: employee engagement, work engagement, leadership behavior

\section{INTRODUCTION}

Employee engagement has generated a great deal of interest in the past three decades because of its significant impact on organizational performance (Anitha, 2014; AON, 2017; Bailey et al., 2017; Chalofsky \& Krishna, 2009; Christian et al., 2011; Harter et al., 2013; Kaur \& Lodhia, 2018; Macey \& Schneider, 2008; Maslach et al., 2001; Saks, 2021; Shuck, 2011; Wefald et al., 2011; Wiley, 2010; Zigarmi et al., 2009). Employee engagement, defined as "a positive, fulfilling, and work-related state of mind that is characterized by vigor, dedication, and absorption" (Schaufeli et al., 2002, p. 465), is a unique construct in organization development (OD). Academic scholars and practitioners have identified that employee engagement is highly correlated with organizational key outcomes, including productivity (Anitha, 2014; Gallup, 2014; Tensay \& Singh, 2020; Winasis et al., 2021), profitability (Schneider et al., 2009; Xanthopoulou et al., 2009), customer satisfaction (Schneider et al., 2009; Tensay \& Singh, 2020), safety performance (Raines, 2011), and employee wellbeing (Shuck \& Reio, 2014; Shuck et al., 2015).

Increased recognition of the strong positive impacts of leadership style on employee engagement has motivated researchers to investigate the impact of leadership on employee engagement in the organization 
(Agarwal et al., 2012; Alok \& Israel, 2012; Book et al., 2019; Den Hartog \& Belschak, 2012; Popli \& Rizvi, 2016; Wang \& Bird, 2011; Wefald et al., 2011; Xu \& Thomas, 2011).

\section{Leadership Behavior Model}

In 1950s, researchers at The Ohio State University identified two types of leadership behavior: Initiating Structure and Consideration. Independently, scholars in the University of Michigan also identified two types of leadership behavior: Goal Emphasis \& Work facilitation, and Leader Support \& Interaction Facilitation (Hughes et al., 2019). The initiating structure is similar to the goal emphasis behavior while the consideration behavior is similar to the support and interaction facilitation behavior.

Initiating structure behavior, consideration behavior, goal emphasis \& work facilitation behavior, and leader support \& interaction facilitation behavior evolved to task-oriented (or initiating structure) and relation-oriented (or employee-oriented) behaviors. The task-oriented leaders are focusing their behaviors on the organizational structure, the operating procedures and they tend to keep control. They may still be concerned with their staff motivation; however, it is not their main concern. The relation (or employee)oriented leaders are focusing their behaviors on satisfying the needs of the team members. Thus, they nurture and maintain constructive relations with team members to motivate them. Relation-oriented leaders still focus on the task and the results; they just achieve them through different means.

A third type of leadership behavior, development- or change-oriented behavior, was introduced in the 1990s by European scholars as an observation of increasing change pressure in society and organizations (Fernandez, 2008; Larsson \& Vinberg, 2010). Leaders with change-oriented behaviors are agile and adaptive to external conditions and environmental relations and are effective at identifying the optimal factors that help strategic initiatives for the organization. This type of leader advocates "experimentation, innovation, risk taking, adaptation, and organizational change" (Fernandez, 2008, p.179). Change-oriented leadership behavior is an important aspect of transformational leadership.

Yukl et al. (2019) reviewed what had been learned about effective leadership behavior from research conducted over more than half a century and introduced a fourth leadership behavior, external-oriented behavior. In addition to influencing internal work unit, a leader can facilitate work performance through providing information of outside events, getting resources, and promoting the interests of the work unit. Yukl et al. identified three distinct external behaviors: networking, external monitoring and representing.

\section{Leadership Behavior-Employee Engagement Relationship}

$\mathrm{Xu}$ and Thomas (2011) studied the effect of task-oriented leadership behavior and relation-oriented leadership behavior on employee engagement in a sample of 178 employees from one organization who rated the leadership behavior of their immediate manager and self-reported their level of engagement using the organization's 360-degree employee appraisal tool. Results found both task- and relation-oriented leadership behaviors are positively related to employee engagement. Additionally, results suggested that relation-oriented leadership behavior is a stronger predictor of employee engagement than task-oriented leadership behavior. Xu and Thomas' work has strengthened what Fernandez (2008) found regarding the positive relationship between relation-oriented leadership behavior and employee job satisfaction and suggest continued research should investigate the correlation between task-oriented and relation-oriented leadership behavior and employee engagement.

Wang and Bird (2011) investigated the relationship between leadership behavior and employee engagement in a sample of 917 school teachers who self-reported their engagement and rated their principals' authentic leadership behavior. Leadership behavior was measured with the 16-item scale of authentic leadership questionnaire (ALQ) developed by Walumbwa et al. (2008). Teacher's engagement was measured using the Gallup Workplace Audit $\left(\mathrm{Q}^{12}\right)$. Their results found a strong positive correlation between authentic leadership behavior and employee engagement. The relationship between authentic leadership behavior and employee engagement was also studied by Alok and Israel (2012) in a sample of 117 employees who rated their supervisors using the ALQ and self-reported their engagement via the UWES (Schaufeli et al., 2006). Results found a positive relationship between authentic leadership and employee engagement. 
In a sample of 167 supervisor-employee dyads, Den Hartog and Belschak (2012) found that ethical leadership behavior was positively correlated with employee engagement, and engagement positively mediated the relationship between ethical leadership and personal initiative, and negatively mediated the relationship between ethical leadership and employee's counterproductive behavior. In their study, subordinates rated their supervisors leadership behavior using the Brown et al. (2005) ten-item scale of ethical leadership behavior; subordinates self-reported their engagement via the UWES (Schaufeli et al., 2006). Agarwal et al. (2012) also found a positive relationship between leadership behavior and employee engagement in a sample of 979 employees. Subordinates rated leadership behavior using Scandura and Graen (1984) seven-item scale of leader-member exchange, and they rated their engagement via the UWES (Schaufeli et al., 2006).

Recently, Book et al. (2019) studied the relationship between leader behavior and employee engagement in a sample of 373 employees working at a large Southwestern U.S. hotel and casino resort. Participants rated their leaders' behavior using a six-item scale by Graen and Uhl-Bien (1995). Participants rated their engagement in terms of physical, emotional and cognitive dimensions using a 12-item scale by Rich et al. (2010). Results found leader behavior was a significant predictor of employee engagement.

Collectively, these studies support the positive impact leadership behavior appears to have on employee engagement. However, none of these studies have specifically investigated the relationship between taskoriented, relation-oriented and change-oriented leadership behaviors and employee engagement.

\section{DESIGN/METHODOLOGY/APPROACH}

In this study we investigated the relationship between leadership behavior and employee engagement in a sample of working professionals. Task-oriented, relation-oriented, and change-oriented leadership behavior were measured along 12 sub-categories of leadership behavior according to the Hierarchical Taxonomy of Leadership Behaviors (Yukl et al., 2002). Employee engagement was measured by the 17item The Utrecht Work Engagement Scale (Schaufeli et al., 2006). Figure 1 presents the conceptual model used in this study.

As shown in the conceptual model (Figure 1), three hypotheses $\left(\mathrm{H}_{1}\right.$ through $\left.\mathrm{H}_{3}\right)$ tested the impact of the three types of leadership behavior (the independent variables) on employee engagement (the dependent variable). Hypotheses $\mathrm{H}_{4}$ through $\mathrm{H}_{6}$ tested the moderation effects of employee age, seniority, and management status on the leadership behavior-employee engagement relationship.

\section{Hypotheses}

Given the inconclusive results of previous research on the relationships between leadership behavior and employee engagement, this study tested the following six hypotheses:

\section{$\boldsymbol{H}_{1}$ : Task-oriented leadership behavior is a positive predictor of employee engagement.}

$\mathrm{H}_{2}$ : Relation-oriented leadership behavior is a positive predictor of employee engagement.

$\boldsymbol{H}_{3}$ : Change-oriented leadership behavior is a positive predictor of employee engagement.

$\boldsymbol{H}_{4}:$ The relationship between leadership behavior and employee engagement is moderated by employee's age.

$H_{5}:$ The relationship between leadership behavior and employee engagement is moderated by employee's seniority.

$\boldsymbol{H}_{6:}$ The relationship between leadership behavior and employee engagement is moderated by employee's management position. 


\section{FIGURE 1 \\ CONCEPTUAL MODEL OF THE STUDY: THE IMPACT OF LEADERSHIP BEHAVIOR ON EMPLOYEE ENGAGEMENT}

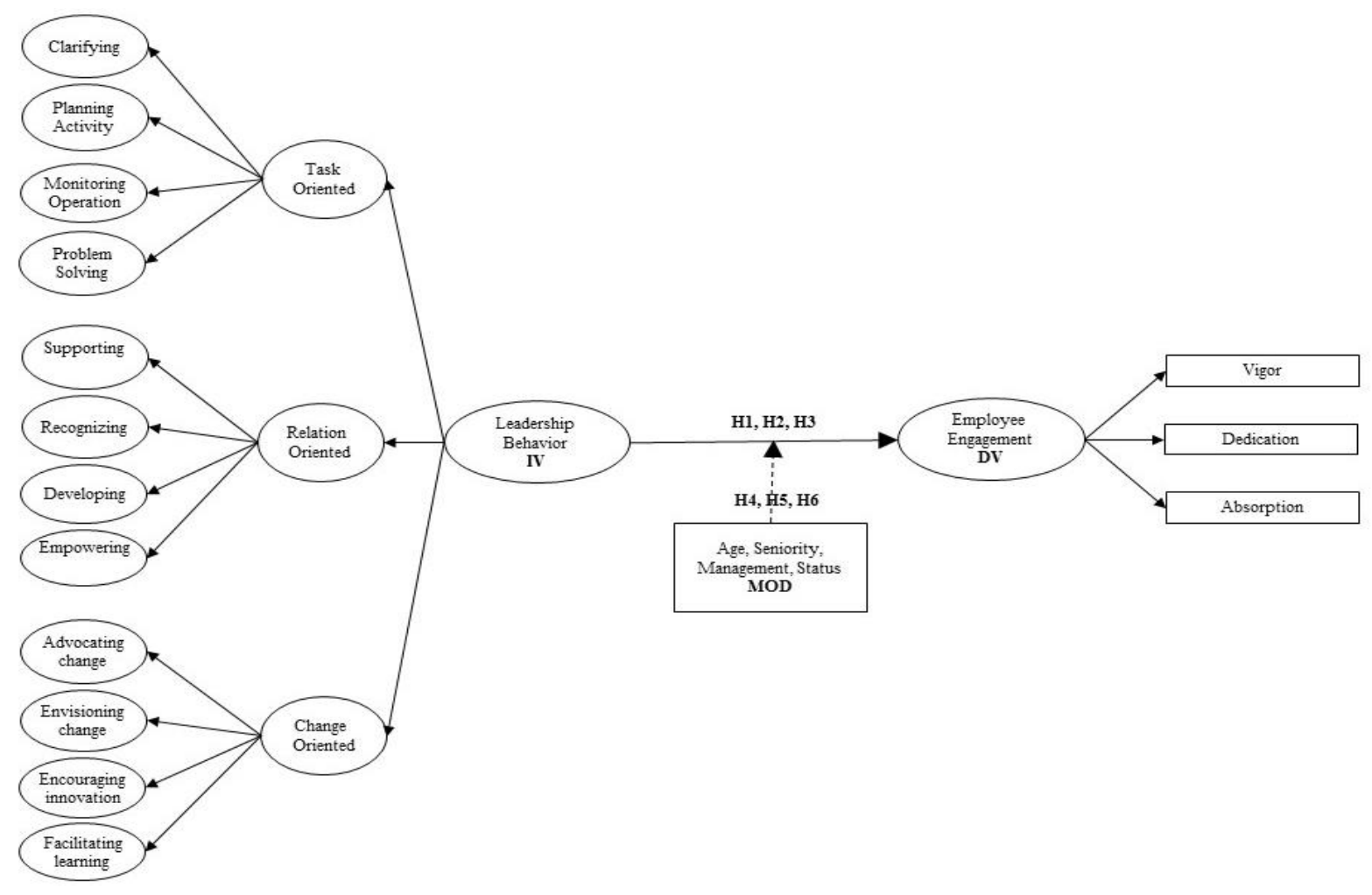

\section{Study Sample}

The sample for this study was randomly selected from the population of LinkedIn groups members who were currently employed subordinates with an immediate supervisor. According to a power analysis using $\mathrm{G}^{*}$ Power 3.1 (Faul et al., 2009; Faul et al., 2007)), the final sample of $\mathrm{N}=117$ was sufficient to obtain a power of 0.80, an alpha of 0.05 (95\% significance level), and an effect size of 0.08 (considered a small-tomedium effect size). Table 1 presents the sample characteristics.

\section{Measures}

Participants rated their immediate supervisors' leader behavior using Yukl et al.'s (2012) 48-item Hierarchical Taxonomy of Leadership Behaviors which measures task-oriented, relation-oriented and change-oriented leadership behaviors using 5-point Likert scales with $1=$ "Not at all or not applicable" to $5=$ "To a very great extent."

The Utrecht Work Engagement Scale (UWES) was used to measure self-reported employee engagement. UWES has been tested and validated extensively, and has been translated into 13 languages (Schaufeli et al., 2006). The 17 items of the UWES are grouped into three subscales that reflect the underlying dimensions of engagement: Vigor (6 items), Dedication (5 items), and Absorption (6 items). All items were scored on a 7-point frequency rating using Likert scale ranging from 0 (never) to 6 (always). 
TABLE 1

CHARACTERISTICS OF STUDY SAMPLE

\begin{tabular}{llllll}
\hline Characteristic & $\mathrm{N}$ & $\%$ & Characteristic & $\mathrm{N}$ & $\%$ \\
\hline $\begin{array}{l}\text { Total Sample } \\
\text { Gender }\end{array}$ & 117 & 100 & Leadership Responsibility & & \\
Female & $38^{* *}$ & 32.5 & No & $50^{*}$ & 42.7 \\
Male & 74 & 63.2 & Not Answered & 61 & 52.1 \\
Not answered & 5 & 4.3 & Seniority & 6 & 5.1 \\
Age & & & Less than one year & $15^{* *}$ & 12.8 \\
$18-29$ & $10^{* *}$ & 8.5 & 1 - 5 years & 49 & 41.9 \\
$30-39$ & 20 & 17.1 & $5-10$ years & 17 & 14.5 \\
$40-49$ & 37 & 31.6 & 10 to 15 years & 10 & 8.5 \\
$50-59$ & 32 & 27.4 & 15 to 20 years & 9 & 7.7 \\
60 and above & 13 & 11.1 & More than 20 years & 10 & 8.5 \\
Not Answered & 5 & 4.3 & Not Answered & 7 & 6 \\
\hline
\end{tabular}

Note. Sample frequency was expressed as \% of all participants, $\mathrm{N}=117$.

$* * p<.01, * p<.05$ Chi-square test for equality of distribution.

\section{Data Analysis}

Survey data were obtained via SurveyMonkey and were analyzed via Minitab 19 and Mplus 8.6 for descriptive and inferential quantitative statistical analysis. Each statistical procedure used all available data.

\section{RESULTS}

\section{Reliability and Validity}

The psychometric properties of the two study measures were evaluated using Cronbach's coefficient alpha test of internal consistency (as an index of reliability) and confirmatory factor analysis (CFA) test of construct validity (Cheung \& Rensvold, 2002). All alpha values were indicative of acceptable reliability for both study measures with alpha $>0.9$ in the study sample (see Table 2). Results of a higher-order CFA conducted on the measurement model shown in Figure 1 were indicative of acceptable construct validity $(\chi 2=3281.59, \mathrm{df}=1987, \mathrm{p}<0.001 ; \mathrm{RMSEA}[90 \% \mathrm{CI}]=0.075$ [0.070-0.079]; CFI = 0.839).

\section{Intercorrelations Between Study Variables}

To examine initial relationships between the variables of interest in this study, zero-order correlation coefficients were evaluated for meaningfulness (see Table 2):

- Leadership behavior composite and employee engagement was significantly and positively correlated

- Task-oriented leadership behavior and employee engagement was significantly and positively correlated

- Relation-oriented leadership behavior and employee engagement was significantly and positively correlated

- Change-oriented leadership behavior and employee engagement was significantly and positively correlated

- Among the three types of leadership behaviors, change-oriented leadership behavior has the strongest correlation with employee engagement (correlation coefficient 0.405 and p-value < 0.05). This finding has not been reported in previous studies 
Among the three constitutive components of employee engagement (vigor, dedication, and absorption), dedication seemed to have the strongest correlation with leadership behavior composite (correlation coefficient 0.416 and p-value $<0.05$ ). Additionally, dedication had the strongest correlation with changeoriented leadership behavior (correlation coefficient 0.449 and p-value $<0.05$ ).

Table 2 also shows that the three types of leadership behavior were positively correlated with each other. This indicates that although task-oriented leadership behavior, relation-oriented leadership, and change-oriented leadership have distinct characteristics, they are not mutually exclusive from each other. A leader who has a high score on one type of leadership behavior may have certain characteristics in other two types of leadership behavior. For example, the characteristics of transformational leadership behavior are: challenging status quo, articulating problems in current state, appealing to follower's values and their sense of higher purpose (Hughes et al., 2019). Transformational leaders also encourage and coach followers to take initiatives and make a difference in the organization and society, which are characteristics of relation-oriented leadership behavior.

TABLE 2

INTERCORRELATIONS BETWEEN STUDY VARIABLES

\begin{tabular}{lllllllll}
\hline Variables & TO & RO & CO & LB & V & D & A & EE \\
\hline TO & 0.962 & & & & & & & \\
RO & $0.806^{*}$ & 0.970 & & & & & & \\
CO & $0.826^{*}$ & $0.924^{*}$ & 0.973 & & & & & \\
LB & $0.921^{*}$ & $0.96^{*}$ & $0.966^{*}$ & 0.985 & & & & \\
V & $0.196^{* *}$ & $0.313^{*}$ & $0.359^{*}$ & $0.308^{*}$ & 0.824 & & & \\
D & $0.305^{*}$ & $0.423^{*}$ & $0.449^{*}$ & $0.416^{*}$ & $0.830^{*}$ & 0.886 & & \\
A & $0.155^{* *}$ & $0.224^{* *}$ & $0.318^{*}$ & $0.245^{* *}$ & $0.754^{*}$ & $0.787^{*}$ & 0.828 & \\
EE & $0.236^{* *}$ & $0.343^{*}$ & $0.405^{*}$ & $0.348^{*}$ & $0.928^{*}$ & $0.939^{*}$ & $0.915^{*}$ & 0.939 \\
\hline Mean & 3.09 & 3.11 & 3.05 & 3.08 & 5.23 & 5.11 & 4.96 & 5.10 \\
SD & 0.97 & 1.06 & 1.04 & 0.98 & 1.02 & 1.18 & 1.04 & 1.00 \\
\hline
\end{tabular}

Note. $\mathrm{N}=117 . * \mathrm{p}<0.05, * * \mathrm{p}<0.01$ Zero-order correlational analysis between task-oriented leadership behavior (TO), relation-oriented leadership behavior (RO), change-oriented leadership behavior (CO), leadership behavior composite (LB), vigor (V), dedication (D), absorption (A), and employee engagement composite (EE). Scale reliability coefficients are shown in the diagonal.

\section{Inferential Statistics}

This section presents the results of regression analyses that were used to test the study hypotheses. Both simple regression and multiple regression were used to test hypotheses 1-3 to evaluate the three leadership behavior factors as positive predictors of employee engagement. Hypotheses 4-6 were tested using hierarchical regression to investigate employee age, seniority and leadership responsibility as moderators of the relationship between leadership behavior and employee engagement.

$\mathrm{H}_{1}$ : Task-oriented leadership behavior is a positive predictor of employee engagement. Results of simple regression conducted to test $H_{l}$ found task-oriented leadership behavior was a significant positive predictor of employee engagement (see Table 3 top panel). As noted by the low R-square (5.6\%), this significant prediction was found to have a relatively small effect size.

$\mathrm{H}_{2}$ : Relation-oriented leadership behavior is a positive predictor of employee engagement. Results of simple regression conducted to test $H_{2}$ found relation-oriented leadership behavior was a significant positive predictor of employee engagement (see Table 3 top panel). The R-square (11.8\%) suggested that this significant prediction had a relatively small effect size. 
$\mathrm{H}_{3}$ : Change-oriented leadership behavior is a positive predictor of employee engagement. Results of simple regression conducted to test $H_{3}$ found change-oriented leadership behavior was a significant positive predictor of employee engagement (see Table 3 top panel). The R-square (16.4\%) showed that this significant prediction had a relatively large effect size.

Since leadership behavior was conceptualized in this study as a multidimensional construct, employee engagement was regressed on the set of all three leadership behavior factors in a multiple regression (see Table 3 bottom panel). As shown, when employee engagement was regressed on the set of all three leadership behavior types in a multiple regression, only change-oriented leadership behavior was found to be the significant predictor.

\section{TABLE 3 \\ EMPLOYEE ENGAGEMENT REGRESSED ON EACH OF THE THREE CONSTITUTIVE TYPES OF LEADERSHIP BEHAVIOR (LINEAR REGRESSION)}

\begin{tabular}{l|llll}
\hline \multirow{2}{*}{ Predictors } & \multicolumn{4}{l}{ Employee Engagement } \\
\cline { 2 - 5 } & $\beta$ & $\mathrm{SE}$ & $\mathrm{T}$ & $\mathrm{R}$-square \\
\hline Leadership Behavior & $0.356^{*}$ & 0.089 & 3.98 & $12.0 \%$ \\
Task-oriented $\left(\mathrm{H}_{1}\right)$ & $0.242^{*}$ & 0.093 & 2.60 & $5.6 \%$ \\
Relation-oriented $\left(\mathrm{H}_{2}\right)$ & $0.321^{*}$ & 0.082 & 3.29 & $11.8 \%$ \\
Change-oriented $\left(\mathrm{H}_{3}\right)$ & $0.389^{*}$ & 0.082 & 4.74 & $16.4 \%$ \\
\hline Task-oriented & -0.300 & 0.157 & -1.92 & $\mathrm{n} / \mathrm{a}$ \\
Relation-oriented & -0.116 & 0.211 & -0.55 & $\mathrm{n} / \mathrm{a}$ \\
Change-oriented & $0.730^{*}$ & 0.227 & 3.22 & $\mathrm{n} / \mathrm{a}$ \\
\hline
\end{tabular}

Note. In the top panel, employee engagement was regressed separately on the mean of each leadership behavior factor; in the bottom panel, employee engagement was regressed simultaneously on the three leadership behavior factors. ${ }^{*} \mathrm{p}$ $<0.05$ significant regression coefficient.

$\mathrm{H}_{4}$ : The relationship between leadership behavior and employee engagement is moderated by employee's age. Results of hierarchical regression found the interaction of leadership behavior and age (LB x Age) was significant (see Table 4 top panel). As shown in Figure 2, leadership behavior had a stronger effect on employee engagement in younger vs. older employees.

$\mathrm{H}_{5}$ : The relationship between leadership behavior and employee engagement is moderated by employee's seniority. Results of hierarchical regression found the interaction of leadership and seniority (LB x Seniority) was not significant (see Table 4 middle panel). As shown in Figure 3, leadership behavior had essentially an equal effect on employee engagement regardless of employee seniority.

$\mathrm{H}_{6}$ : The relationship between leadership behavior and employee engagement is moderated by employee's leadership responsibility. Results of hierarchical regression found the interaction of leadership and leadership responsibility (LB x Leadership Responsibility) was significant (see Table 4 bottom panel). As shown in Figure 4, leadership behavior had a stronger effect on employee engagement in employees without leadership responsibility vs. employees with leadership responsibility. 
TABLE 4

HIERARCHICAL REGRESSION OF EMPLOYEE ENGAGEMENT ON LEADERSHIP BEHAVIOR (LB) AND AGE, SENIORITY, AND LEADERSHIP RESPONSIBILITY

\begin{tabular}{llcc}
\hline & \multicolumn{3}{l}{ Employee Engagement } \\
\cline { 2 - 4 } Variable & Step 1 & Step 2 & Step 3 \\
\hline Leadership Behavior & $0.355^{* * *}$ & $0.408^{* * *}$ & $0.982^{* * *}$ \\
Age & & $0.298^{* *}$ & $0.828^{* *}$ \\
LB x Age & & & $-0.173^{*}$ \\
$R$-square & $12.1 \%$ & $24.0 \%$ & $28.2 \%$ \\
Change in $R$-square & & $11.9 \%^{* *}$ & $4.2 \%^{+}$ \\
\hline Leadership Behavior & $0.355^{* *}$ & $0.323^{* *}$ & $0.436^{*}$ \\
Seniority & & 0.019 & 0.152 \\
LB x Seniority & & & -0.04 \\
$R$-square & $12.1 \%$ & $11.1 \%$ & $11.5 \%$ \\
Change in $R$-square & & $-1.0 \%$ & $0.4 \%$ \\
\hline Leadership Behavior & $0.355^{* *}$ & $0.362^{* *}$ & $0.950^{* *}$ \\
Leadership Responsibility & & $0.368^{*}$ & $1.634^{* *}$ \\
LB x Leadership Responsibility & & & $-0.410^{*}$ \\
$R$-square & $12.1 \%$ & $15.8 \% *$ & $19.7 \%^{*}$ \\
Change in $R$-square & & $3.7 \%$ & $3.9 \%$ \\
\hline
\end{tabular}

Note. See text for coding of variables.

${ }^{+} p<.10,{ }^{*} p<.05,{ }^{* * *} p<.01$ significant regression coefficient or change in $R$-square

FIGURE 2

EMPLOYEE'S AGE AS A MODERATOR OF THE RELATIONSHIP BETWEEN LEADERSHIP BEHAVIOR AND EMPLOYEE ENGAGEMENT

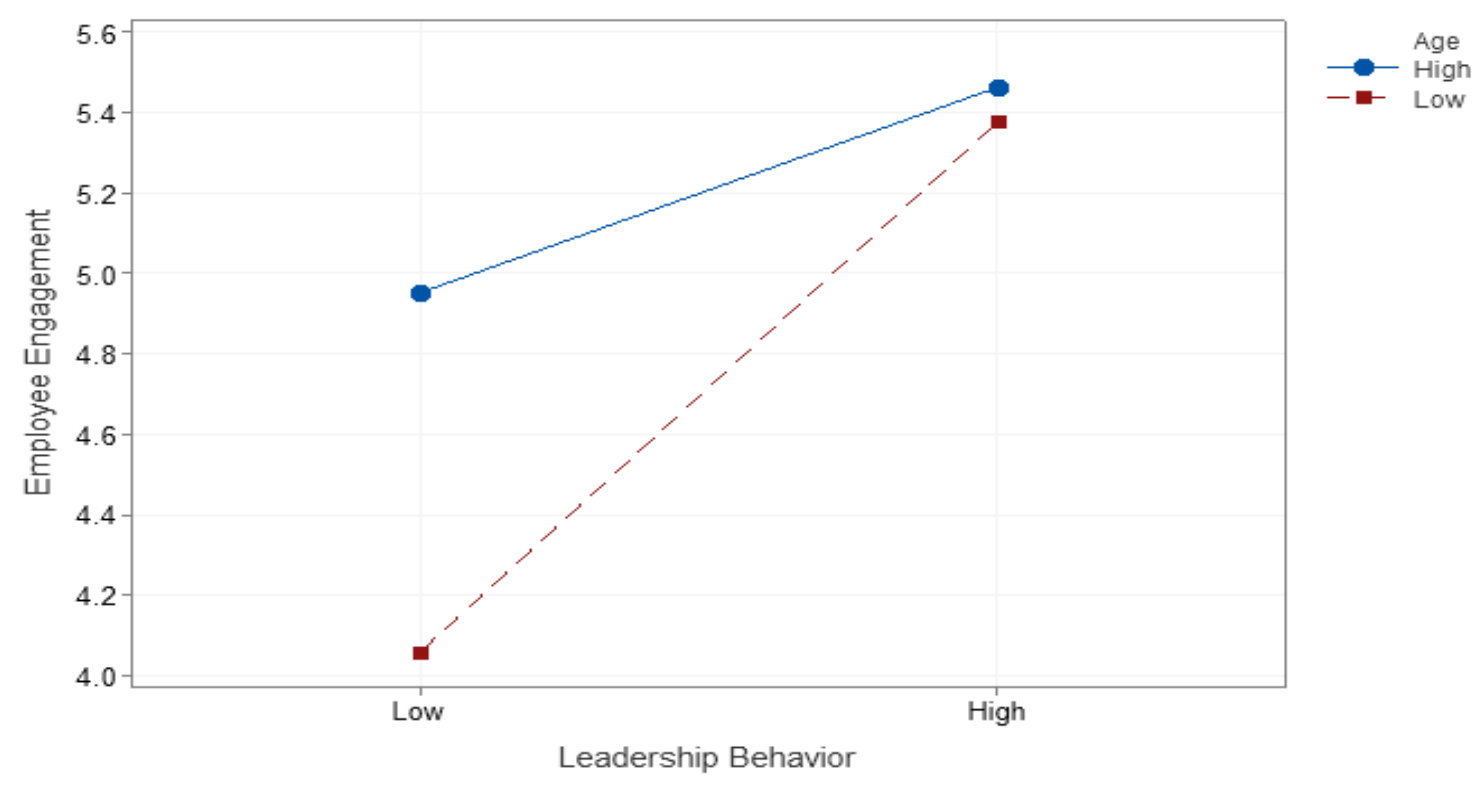


FIGURE 3

EMPLOYEE'S SENIORITY AS A MODERATOR OF THE RELATIONSHIP BETWEEN LEADERSHIP BEHAVIOR AND EMPLOYEE ENGAGEMENT

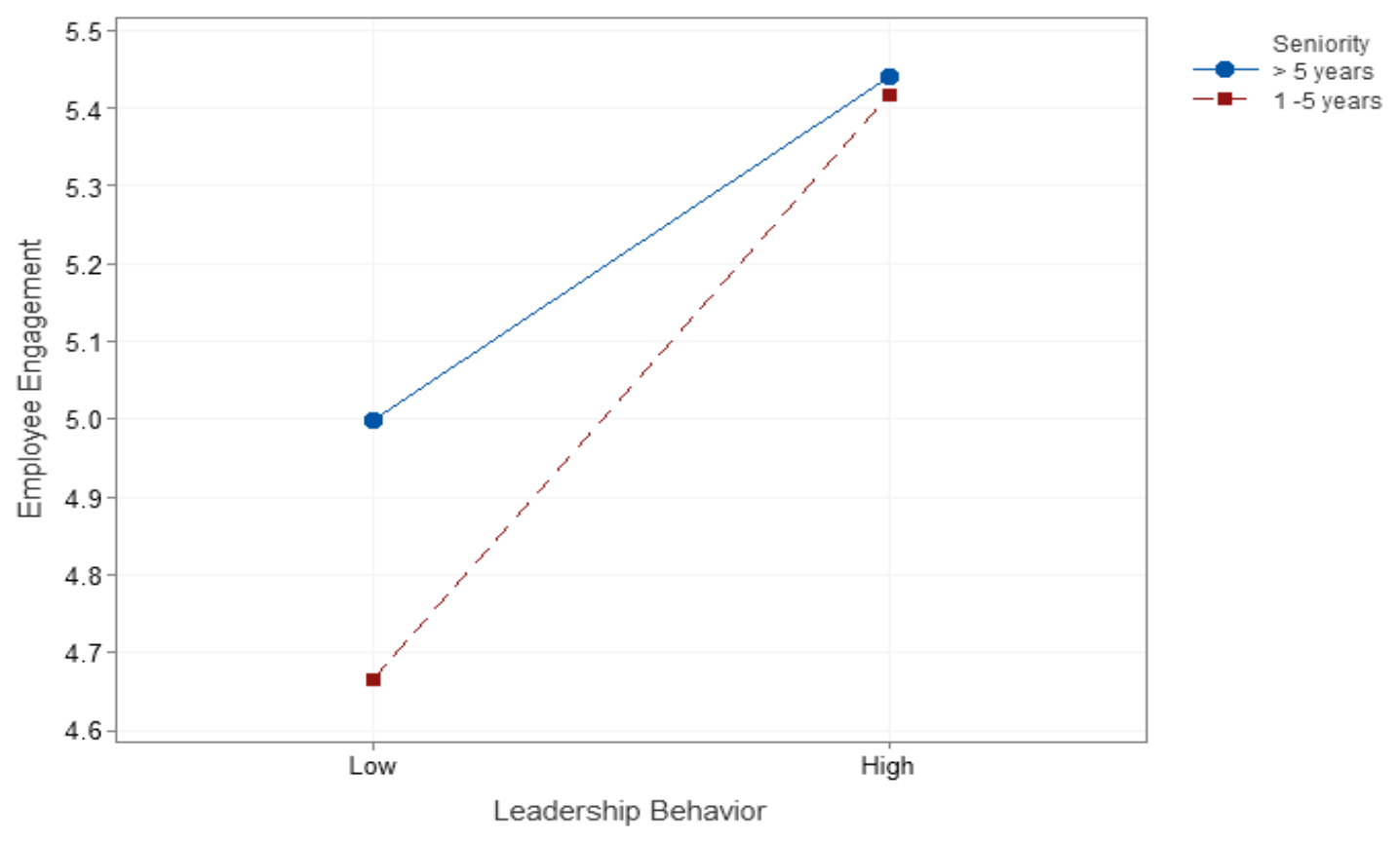

FIGURE 4

EMPLOYEE'S MANAGEMENT STATUS AS A MODERATOR OF THE RELATIONSHIP BETWEEN LEADERSHIP BEHAVIOR AND EMPLOYEE ENGAGEMENT

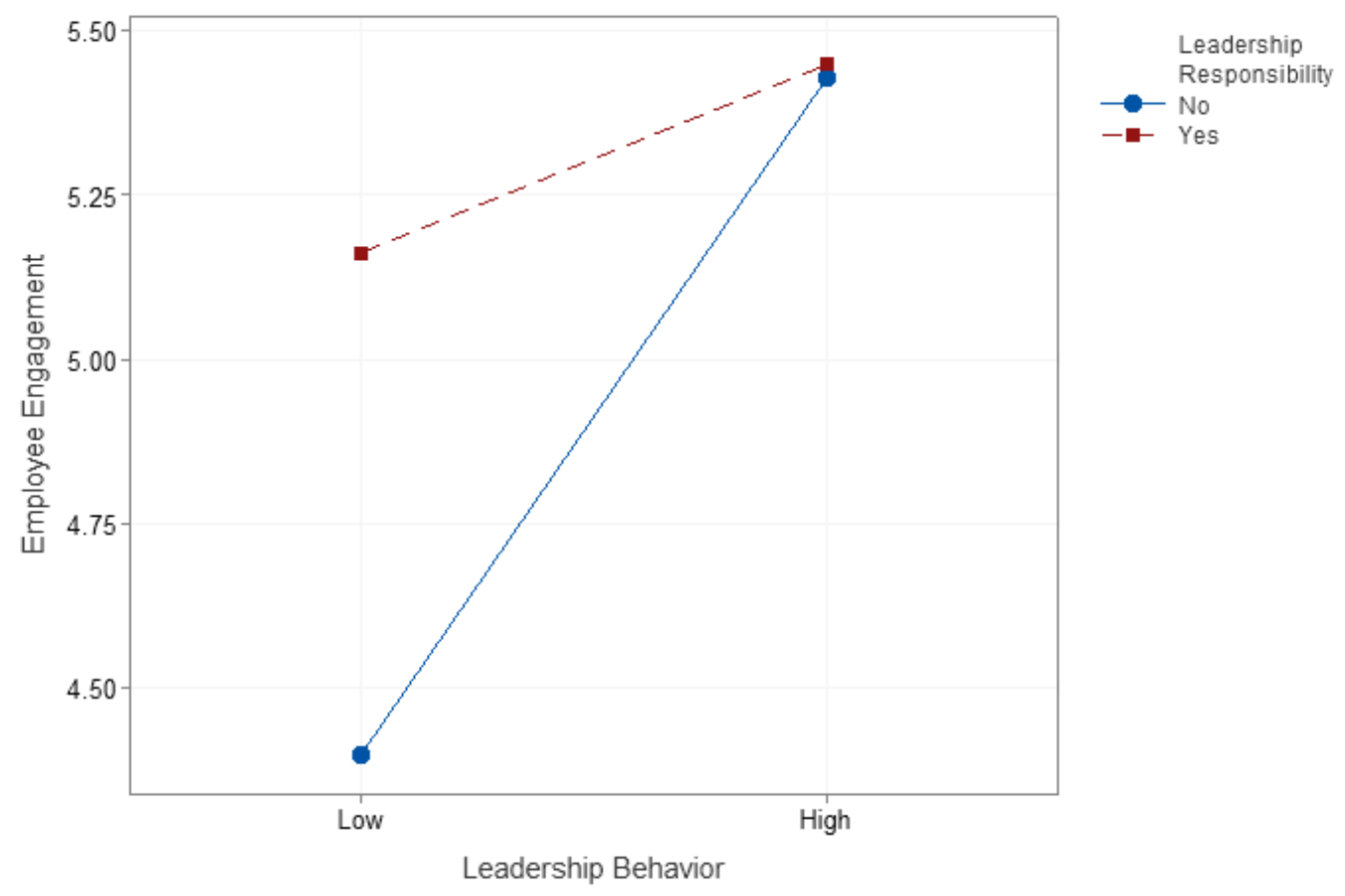




\section{Discussion and Implications for Practice and Recommendations}

This study investigated the relationship between leadership behavior and employee engagement using a quantitative method in which six hypotheses were tested. Results are summarized as follows:

- Task-oriented leadership behavior was a significant positive predictor of employee engagement

- Relation-oriented leadership behavior was a significant positive predictor of employee engagement

- Change-oriented leadership behavior was a significant positive predictor of employee engagement

- Among the three types of leadership behavior (task-oriented, relation-oriented, and changeoriented leadership behavior), change-oriented leadership behavior appeared to be the strongest predictor of employee engagement

- Employee's age was a significant moderator of the relationship between leadership behavior and employee engagement

- Employee's seniority was not a significant moderator of the relationship between leadership behavior and employee engagement

- Employee's management status was a significant moderator of the relationship between leadership behavior and employee engagement. Holding a leadership position may increase the impact of leadership behavior on employee engagement

The strong correlation between change-oriented leadership and employee engagement support results from a number of previous studies. For example, transformational leadership behavior has been suggested to have strong and positive correlation with employee engagement (Bhuvanaiah \& Raya, 2015; Zhu et al., 2009). Transformational leadership has also been linked to change-oriented leadership behavior because transformational leadership is characterized by seeking different perspectives from group members (intellectual stimulation), challenging assumptions, encouraging innovation, and developing and communicating a compelling vision for the future (inspirational motivation)(Derue et al., 2011). Therefore, it can be inferred from previous studies that change-oriented leadership behavior might have strong relationship with employee engagement.

Findings from this research have a number of practical implications for organizational leaders to improve employee engagement. First, since task-oriented, relation-oriented, and change-oriented leadership behaviors all appear to positively impact employee engagement, leaders can therefore focus on leadership behavior that is most closely aligned with the organization's mission, strategies and goals without jeopardizing employee engagement. It is not necessary for a leader who might be more oriented in a type of leadership behavior to force him- or her-self to balance skills among the three types of leadership behavior in order to increase employee engagement. For example, if task-oriented leadership behavior is most appropriate for the organization's situation, leaders can focus on task-oriented leadership with added emphasis on those dimensions of task-orientation that also promote employee engagement such as effective task and resource planning, clarifying roles and responsibilities, setting goals and timelines, and managing performance (Xu \& Thomas, 2011).

A relation-oriented leader may improve employee engagement by showing sincere concerns for employees' needs and wellbeing, providing necessary support for their development, and empowering team members to take more responsibilities and make decision without prior approvals (Aggarwal et al., 2020; Albrecht \& Andreetta, 2011; Saks, 2021; Xu \& Thomas, 2011). Employees who feel they are making a difference in the organizations through the experience of empowerment tend to be more engaged at work place (Albrecht and Andreetta, 2011). Bhuvanaiah and Raya (2015) also suggested that giving employees decision making authority would increase work engagement by satisfying their psychological need for sense of involvement, autonomy, and being valued.

Second, organizations should consider selecting leaders who exhibit strong change-oriented behavior to enhance employee engagement. According to this study, leaders who have strong skills in change leadership behavior could be greatly effective to increase employee engagement. This implies that employees may be more inspired and motivated by leaders who can articulate a clear vision for the team or 
organization, be open to innovation, and nurture a learning culture in the organization. Derue et al. (2011) related change-oriented leadership behavior to transformational leadership characterized by seeking different perspectives from group members (intellectual stimulation), challenging assumptions, encouraging innovation, and developing and communicating a compelling vision for the future (inspirational motivation). Bhuvanaiah and Raya (2015) examined the psychological process that involves while an employee engages at workplace. Their findings suggested that transformational leadership would have higher impact on employee engagement by satisfying employees' psychological need for sense of purpose. Yi et al. (2019) suggested that transformational leaders engage employees to create innovative outcomes through influencing employees' intrinsic motivation and proactive behavior. Yukl (2012) pointed out that leaders with change leadership skills "can propose a strategy for responding to a threat or opportunity, but involving people with relevant expertise usually results in a better strategy and more commitment to implement it" (p. 73).

Third, this study has found that employee's age and leadership responsibility were significant moderators of the relationship between leadership behavior and employee engagement. As shown in Figure 2 , the slope of the leadership behavior-employee engagement relationship was steeper for younger employees, and is shown in Figure 4, the slope of the leadership behavior-employee engagement relationship was steeper for employees without leadership responsibility. Taken together, these results suggest that although older employees and employees with leadership responsibility may be more engaged than their younger colleagues and colleagues without leadership responsibility, the impact on employee engagement by leadership behavior has significant positive impact on younger employees who have not yet been promoted to roles with leadership responsibility - thus, leadership behavior is important for employee engagement in new employees.

The age moderating effect on leadership behavior-employee engagement relationship may be related to the difference of leader-member reciprocity norm (expectation that people will respond favorably to each other by returning benefits for benefits) by employee age group (James et al., 2011). Younger employees have great interest in pursuing career development opportunities; older employees tend to expect to be rewarded for their loyalty (Cappelli, 2014; James et al., 2011). Therefore, to boost engagement among younger employees, leaders should provide them with more guidance for their career development, and more encouragement in terms of roles and responsibilities in the organization. In contrast, to increase engagement level among older employees, leaders must resort to different means, such as involving them more in decision making and recognizing their expertise and contributions to the organizations (James et al., 2011). Additionally, for older employees, work is often a source of social interactions. Leaders should consider assigning older workers with customer interactions (Cappelli, 2014).

Fourth, leaders should be informed of the differences between leader engagement and individual contributor engagement, and thus efforts to increase engagement among leaders may not have the same impact among individual contributors. Employees in leadership positions typically understand better than team members about their organization's priorities, initiatives, and external factors relevant to the organization. They also have access to more resources and have more involvement and power in decision making. Therefore, organizations should be aware of those factors that increase engagement among leaders and may need to spend more time and effort to increase the engagement of their followers. In particular, leaders should clearly and timely communicate to team members about their organization's vision, priorities and reason for significant changes in priorities or initiatives. O'Neill et al. (2015) pointed out that good communication would motivate and engage employees by allowing them to understand current organization's changes and how they should respond (i.e. emotional connection). Additionally, leaders should empower employees to make decisions, provide team members with opportunities for growth and development (Bhuvanaiah \& Raya, 2015).

Fifth, results of the hierarchical regression with seniority found that seniority was not a moderator of the leadership behavior-employee engagement relationship. This finding was unexpected given that age was found to be a moderator of the leadership behavior-employee engagement relationship and the expectation was that age and seniority would be similar with regards to employee engagement. However, employee engagement was significantly different across age. These results support the difference in 
moderation between age and seniority. In today's organizations, employees enter the organizations at different ages due to globalization, technological changes, and intensifying competition (Goldberg, 2014), thus there is a dissociation between age and seniority because younger employees may have more seniority than older employees. Table 5 presents a summary of implications for practice and recommendations.

\section{Limitations}

While the findings of this research are statistically significant, the results may have certain limitations. The first study limitation concerns leadership behavior and its measurement in the current study. Specifically, given the logistical challenges of forming employee-supervisor dyads, supervisor leadership behavior was measured by subordinates of leaders rather than by leaders themselves. Since the subordinates provided ratings of their leaders' behavior, and provided ratings of their individual level of employee engagement, the relationship between leadership behavior and employee engagement in this study was valid from the perspective of the employee but may not be valid from the perspective of the leader.

The second study limitation concerns the potential for common-method bias to have occurred. Common-method bias may occur when data for the study's independent variable is obtained from the same source that provides data for the study dependent variable. Such bias is attributable to the measurement method rather than to the constructs the measures represent (Donaldson \& Grant-Vallone, 2002). To test for the occurrence of common-method bias in the study data, Harman's single factor test was conducted (Podsakoff et al., 2003). Specifically, a one-factor exploratory factor analysis (EFA) was conducted on the items that measured leadership behavior and employee engagement, and eigenvalues were found indicative of a multi-factorial result. Specifically, if the EFA found only one factor emerged, the study data are likely to be negatively impacted by common-method bias. Although common-method bias does not appear to have occurred in this study, obtaining data on leadership behavior from multiple sources, in addition to the employee, will reduce the potential for common-method bias to occur in the future.

TABLE 5

\section{LEADERSHIP APPLICATIONS FOR IMPROVING EMPLOYEE ENGAGEMENT}

\begin{tabular}{|c|c|c|c|c|c|}
\hline \multirow{3}{*}{$\begin{array}{l}\text { Application } \\
\text { Research } \\
\text { findings }\end{array}$} & \multicolumn{2}{|c|}{ Type of Leadership Behavior } & \multirow[b]{2}{*}{$\begin{array}{l}\text { Change- } \\
\text { oriented } \\
\text { Positively } \\
\text { correlated } \\
\text { with EE }\end{array}$} & \multicolumn{2}{|c|}{ Employee Characteristics } \\
\hline & $\begin{array}{l}\text { Task- } \\
\text { oriented } \\
\text { Positively } \\
\text { correlated } \\
\text { with EE }\end{array}$ & $\begin{array}{l}\text { Relation- } \\
\text { oriented } \\
\text { Positively } \\
\text { correlated with } \\
\text { EE }\end{array}$ & & $\begin{array}{l}\text { Age } \\
\text { Positively } \\
\text { correlated with } \\
\text { EE }\end{array}$ & $\begin{array}{l}\text { Management } \\
\text { Status } \\
\text { Positively } \\
\text { correlated with } \\
\text { EE }\end{array}$ \\
\hline & $\begin{array}{l}\text { Significant } \\
\text { predictor of } \\
\text { EE }\end{array}$ & $\begin{array}{l}\text { Significant } \\
\text { predictor of } \\
\text { EE }\end{array}$ & $\begin{array}{l}\text { Strongest } \\
\text { predictor of } \\
\text { EE }\end{array}$ & $\begin{array}{l}\text { Negative } \\
\text { moderation on } \\
\text { LB-EE } \\
\text { relationship }\end{array}$ & $\begin{array}{l}\text { Positive } \\
\text { moderation on } \\
\text { LB-EE } \\
\text { relationship }\end{array}$ \\
\hline $\begin{array}{l}\text { Literature } \\
\text { support }\end{array}$ & $\begin{array}{l}\text { Focusing on } \\
\text { effective } \\
\text { task and } \\
\text { resource } \\
\text { planning } \\
\text { (Xu \& } \\
\text { Thomas, } \\
2011 \text { ) } \\
\text { Clarifying } \\
\text { roles and }\end{array}$ & $\begin{array}{l}\text { Showing } \\
\text { sincere } \\
\text { concerns for } \\
\text { employees' } \\
\text { needs (Xu \& } \\
\text { Thomas, 2011) } \\
\text { Providing } \\
\text { necessary } \\
\text { support for } \\
\text { their }\end{array}$ & $\begin{array}{l}\text { Expecting } \\
\text { higher EE } \\
\text { through } \\
\text { change } \\
\text { leadership } \\
\text { behavior } \\
\text { (Bhuvanaiah } \\
\text { \& Raya, } \\
\text { 2015; Derue } \\
\text { et al., 2011; } \\
\text { Yukl, 2012) }\end{array}$ & $\begin{array}{l}\text { Recognizing } \\
\text { older } \\
\text { employees for } \\
\text { their loyalty } \\
\text { (James et al., } \\
\text { 2011) } \\
\text { Involving older } \\
\text { employees } \\
\text { more in } \\
\text { decision }\end{array}$ & $\begin{array}{l}\text { Understanding } \\
\text { factors that } \\
\text { increase } \\
\text { engagement } \\
\text { among leaders } \\
\text { (Xu \& Thomas, } \\
2011 \text { ) } \\
\text { Clearly and } \\
\text { timely } \\
\text { communicating }\end{array}$ \\
\hline
\end{tabular}




\begin{tabular}{|c|c|c|c|c|c|}
\hline & $\begin{array}{l}\text { responsibil- } \\
\text { ities (Yukl, } \\
\text { 2012) } \\
\text { Setting clear } \\
\text { goals and } \\
\text { timelines } \\
\text { (Yukl, } \\
\text { 2012) } \\
\text { Managing } \\
\text { performance } \\
\text { (Xu \& } \\
\text { Thomas, } \\
\text { 2011) }\end{array}$ & $\begin{array}{l}\text { development } \\
\text { (Bhuvanaiah } \\
\text { \& Raya, 2015) } \\
\text { Empowering } \\
\text { team members } \\
\text { to take more } \\
\text { responsibilities } \\
\text { and make } \\
\text { decision } \\
\text { without prior } \\
\text { approvals } \\
\text { (Albrecht \& } \\
\text { Andreetta, } \\
\text { 2011; } \\
\text { Bhuvanaiah \& } \\
\text { Raya, 2015; } \\
\text { Xu \& Thomas, } \\
\text { 2011) }\end{array}$ & $\begin{array}{l}\text { Organizations } \\
\text { should select } \\
\text { leaders who } \\
\text { exhibit strong } \\
\text { change- } \\
\text { oriented } \\
\text { behavior to } \\
\text { enhance } \\
\text { employee } \\
\text { engagement } \\
\text { (Bhuvanaiah } \\
\text { \& Raya, } \\
\text { 2015; Derue } \\
\text { et al., 2011; } \\
\text { Yukl, 2012) }\end{array}$ & $\begin{array}{l}\text { making (James } \\
\text { et al., 2011) } \\
\text { Assign older } \\
\text { employees to } \\
\text { interact with } \\
\text { customers } \\
\text { (Cappelli, } \\
\text { 2014) } \\
\text { Provide more } \\
\text { guidance for } \\
\text { career } \\
\text { development, } \\
\text { encouragement, } \\
\text { and motivation } \\
\text { for younger } \\
\text { employees } \\
\text { (James et al., } \\
\text { 2011) }\end{array}$ & $\begin{array}{l}\text { to team } \\
\text { members about } \\
\text { organization's } \\
\text { vision, } \\
\text { priorities and } \\
\text { reasons for } \\
\text { significant } \\
\text { changes in } \\
\text { priorities or } \\
\text { initiatives } \\
\text { (O’Neil et al., } \\
\text { 2015) } \\
\text { Empowering } \\
\text { employees to } \\
\text { make decisions } \\
\text { (Bhuvanaiah \& } \\
\text { Raya, 2015) } \\
\text { Provide } \\
\text { employees with } \\
\text { necessary } \\
\text { resources to } \\
\text { help } \\
\text { accomplish } \\
\text { their tasks } \\
\text { (Bhuvanaiah \& } \\
\text { Raya, 2015) }\end{array}$ \\
\hline $\begin{array}{l}\text { Summary of } \\
\text { recommendations }\end{array}$ & \multicolumn{5}{|c|}{$\begin{array}{l}\text { Leaders can and should focus on leadership behavior that is most closely aligned } \\
\text { with the organization's mission, strategies and goals without jeopardizing employee } \\
\text { engagement. In situations where the organization needs to focus on improving } \\
\text { employee engagement, it should select candidates with change-oriented leadership } \\
\text { behaviors for leadership positions. Organizations should be sensitive to employee's } \\
\text { characteristics, such as age and management status, when implementing employee } \\
\text { engagement strategies. }\end{array}$} \\
\hline
\end{tabular}

The third potential study limitation concerns the study design. Specifically, the study obtained crosssectional survey data, which may limit the generalizability of the study results due to the collection of data at only one moment in time. The collection of data on leadership behavior and employee engagement over multiple time periods (longitudinal study) may increase the generalizability of the study results.

\section{Recommendations for Future Research}

There are several suggestions for further study on the relationship between leadership behavior and employee engagement. This study investigated the relationship between three types of (task-oriented, relation-oriented, and change-oriented) leadership behavior and employee engagement. The fourth type, external oriented leadership behavior, should be included in future studies on this subject. Specific characteristics of external-oriented leadership behavior include networking, external monitoring, and representing. Studies have found that external-oriented leadership behaviors can be related to leadership effectiveness, similar to other types of leadership behavior (Yukl, 2012). It would be interesting to understand that among the four types of (task-oriented, relation-oriented, change-oriented, and externaloriented) leadership behavior, which type would have the strongest impact on employee engagement. 
The second recommendation is to obtain data on leadership behavior from multiple sources to reduce the potential for common-method bias to occur. For example, a 360 approach to assess leadership behavior would provide responses from the subordinates, the leaders and their peers, stakeholders, etc.

The third suggestion is to investigate why change-oriented leadership behavior was found to have stronger impact on employee engagement than task-oriented and relation-oriented leadership behaviors. Possible factors may include the importance of innovation and changes required or driven by the increasing risk in today's economy and business environment, the need for collaboration and shared learning, and the difficulties of implementing major changes in strategies. Additionally, similar to Bhuvanaiah and Raya (2015)'s study, a possible avenue can be exploring the psychological process related to impact of changeoriented leadership behavior on employee engagement.

The fourth recommendation for future study is to understand the impact of leadership behavior on the individual components of employee engagement-vigor, dedication, and absorption.

The fifth recommendation for future study is to investigate the moderation effects of employee age, seniority, and management status on the impact of each of the three leadership behaviors, task-oriented, relation-oriented, and change-oriented, on employee engagement.

The sixth recommendation for future study is to explore the relationship between leadership and employee engagement in different cultures. It may be intuitive to think that the impact of leadership behavior on employee engagement is different in different cultural environments, and measures of effective leadership behavior vary among cultures (Hwang et al., 2015).

The seventh suggestion for future study is to investigate the relationship between leadership behavior and employee engagement in for-profit and non-profit organizations separately. Goals and purposes are very different between for-profit and not-for-profit organizations. Factors that affect employee engagement can be very different for for-profit than for not-for-profit organizations. For example, for-profit organizations primarily focus on maximizing profits while not-for-profit organizations mostly focus on improving public benefits (Birdi et al., 2007).

A final suggestion for future study is to investigate the relationship between leadership behavior and employee engagement in different industry sectors. For instance, the management-labor relationship in high tech industries can be very different from these relationships in traditional manufacturing industries. Factors affecting employee engagement in union-based corporations might be different from those in high tech companies.

\section{CONCLUSION}

Since employee engagement has been found to significantly affect an organization's performance (Anitha, 2014; AON, 2017; Gallup, 2014; Schneider et al., 2009; Tensay \& Singh, 2020; Xanthopoulou et al., 2009), organizations worldwide have invested significant amount of resources to improve employee engagement, and thus are looking for guidance on how their leaders can most effectively improve employee engagement, and ultimately organizational performance (Shuck \& Herd, 2012). It was disappointing that few studies had investigated the impact of leadership behavior on employee engagement. This study investigated the relationship between three types of (task-oriented, relation-oriented, and change-oriented) leadership behavior and employee engagement. Results have provided strong suggestions that all three types of leadership behavior can positively affect engagement. Additionally, this study suggested that change-oriented leadership behavior appeared to have the most impact on employee engagement which had not be reposted in previous studies.

The implications from this current study are that leaders can and should focus on leadership behavior that is most closely aligned with the organization's mission, strategies and goals without jeopardizing employee engagement. In situations where the organization needs to focus on improving employee engagement, it should select candidates with characteristics of change-oriented leadership behavior for leadership positions. The case for this type of leadership is especially important in last two years as employees, organizations, and societies have been faced with unexpected events and transitioned from COVID 19 crisis to recovery, and the new "norm". A recent study by McKinsey (2021) indicates that 
$90 \%$ of business leaders believe future work is a combination of remote and on-site work, but about $68 \%$ have no specific plans for the implementation. Change-oriented leaders will explain to employees the reasons for certain changes and help them see the benefits through clear communications (van den Heuvel et al., 2020). In addition, change-oriented leaders will develop the process and facilitate the learning and adaptation to new business models.

\section{REFERENCES}

Agarwal, U.A., Datta, S., Blake-Beard, S., \& Bhargava, S. (2012). Linking LMX, innovative work behaviour and turnover intentions. Career Development International, 17(3), 208-230. doi.org/10.1108/13620431211241063

Aggarwal, A., Chand, P.K., Jhamb, D., \& Mittal, A. (2020). Leader-member exchange, work engagement, and psychological withdrawal behavior: The mediating role of psychological empowerment. Frontiers in Psychology, 11, 423-423. doi.org/10.3389/fpsyg.2020.00423

Albrecht, S.L., \& Andreetta, M. (2011). The influence of empowering leadership, empowerment and engagement on affective commitment and turnover intentions in community health service workers: Test of a model. Leadership in Health Services, 24(3), 228-237.

Alok, K., \& Israel, D. (2012). Authentic leadership \& work engagement. Indian Journal of Industrial Relations, 47(3), 498-510. Retrieved from www.jstor.org/stable/23267340

Anitha, J. (2014). Determinants of employee engagement and their impact on employee performance. International Journal of Productivity and Performance Management, 63(3), 308-323. doi.org/10.1108/IJPPM-01-2013-0008

AON. (2017). 2017 trends in global employee engagement. Retrieved from https://www.aon.com/engagement17/index.aspx

Bailey, C., Madden, A., Alfes, K., \& Fletcher, L. (2017). The meaning, antecedents and outcomes of employee engagement: A narrative synthesis. International Journal of Management Reviews, 19(1), 31-53. doi.org/10.1111/ijmr.12077

Bhuvanaiah, T., \& Raya, R.P. (2015). Mechanism of improved performance: Intrinsic motivation and employee engagement. SCMS Journal of Indian Management, 12(4), 92-97.

Birdi, K.S., Patterson, M.G., \& Wood, S.J. (2007). Learning to perform? A comparison of learning practices and organizational performance in profit- and non-profit-making sectors in the UK. International Journal of Training and Development, 11(4), 265-281. doi.org/10.1111/j.14682419.2007.00285.x

Book, L., Gatling, A., \& Kim, J. (2019). The effects of leadership satisfaction on employee engagement, loyalty, and retention in the hospitality industry [Article]. Journal of Human Resources in Hospitality \& Tourism, 18(3), 368-393. doi.org/10.1080/15332845.2019.1599787

Brown, M.E., Treviño, L.K., \& Harrison, D.A. (2005). Ethical leadership: A social learning perspective for construct development and testing. Organizational Behavior and Human Decision Processes, 97(2), 117-134. doi.org/10.1016/j.obhdp.2005.03.002

Cappelli, P. (2014). Engaging Your Older Workers [Article]. Harvard Business Review Digital Articles, pp. $2-4$.

Chalofsky, N., \& Krishna, V. (2009). Meaningfulness, commitment, and engagement: The intersection of a deeper level of intrinsic motivation. Advances in Developing Human Resources, 11(2), 189203. doi.org/10.1177/1523422309333147

Cheung, G.W., \& Rensvold, R.B. (2002). Evaluating goodness-of-fit indexes for testing measurement invariance. Structural Equation Modeling, 9(2), 233-255. doi.org/10.1207/S15328007SEM0902_5

Christian, M.S., Garza, A.S., \& Slaughter, J.E. (2011). Work engagement: A quantitative review and test of its relations with task and contextual performance. Personnel Psychology, 64(1), 89-136. doi.org/10.1111/j.1744-6570.2010.01203.x 
Den Hartog, D.N., \& Belschak, F.D. (2012). Work engagement and machiavellianism in the ethical leadership process. Journal of Business Ethics, 107(1), 35-47. doi.org/10.1007/s10551-012-12964

Derue, D.S., Nahrgang, J.D., Wellman, N.E.D., \& Humphrey, S.E. (2011). Trait and behavioral theories of leadership: An integration and meta-analytic test of their relative validity. Personnel Psychology, 64(1), 7-52. doi.org/10.1111/j.1744-6570.2010.01201.x

Donaldson, S.I., \& Grant-Vallone, E.J. (2002). Understanding self-report bias in organizational behavior research. Journal of Business and Psychology, 17(2), 245-260. doi.org/10.1023/A:1019637632584

Faul, F., Erdfelder, E., Buchner, A., \& Lang, A.G. (2009). Statistical power analyses using G*Power 3.1: Tests for correlation and regression analyses. Behavior Research Methods, 41(4), 1149-1160.

Faul, F., Erdfelder, E., Lang, A.G., \& Buchner, A. (2007). G*Power 3: A flexible statistical power analysis program for the social, behavioral, and biomedical sciences. Behavior Research Methods, 39(2), 175-191.

Fernandez, S. (2008). Examining the effects of leadership behavior on employee perceptions of performance and job satisfaction. Public Performance \& Management Review, 32(2), 175-205. doi.org/10.2753/PMR1530-9576320201

Gallup. (2014). Majority of U.S. employees not engaged despite gains in 2014. Retrieved from http://www.gallup.com/poll/181289/majority-employees-not-engaged-despite-gains-2014.aspx

Goldberg, J. (2014). Trends in employee turnover and retention [Article]. Graziadio Business Review, 17(3), 1-5.

Graen, G.B., \& Uhl-Bien, M. (1995). Relationship-based approach to leadership: Development of leadermember exchange (LMX) theory of leadership over 25 years: Applying a multi-level multidomain perspective. Leadership Quarterly, 6(2), 219-247.

Harter, J.K., Schmidt, F.L., Agrawal, S., \& Plowman, S.K. (2013). The relationship between engagement at work and organizational outcomes. The Gallup Organization.

Hughes, R., Ginnett, R., \& Curphy, G. (2019). Leadership: Enhancing the lessons of experence (9th ed.). McGraw Hill Education.

Hwang, S.J., Quast, L.N., Center, B.A., Chung, C-T.N., Hahn, H-J., \& Wohkittel, J. (2015). The impact of leadership behaviours on leaders' perceived job performance across cultures: Comparing the role of charismatic, directive, participative, and supportive leadership behaviours in the U.S. and four Confucian Asian countries. Human Resource Development International, 18(3), 259-277. doi.org/10.1080/13678868.2015.1036226

James, J.B., McKechnie, S., \& Swanberg, J. (2011). Predicting employee engagement in an age-diverse retail workforce. Journal of Organizational Behavior, 32(2), 173-196. doi.org/10.1002/job.681

Kaur, A., \& Lodhia, S. (2018). Stakeholder engagement in sustainability accounting and reporting: A study of Australian local councils. Accounting, Auditing \& Accountability Journal, 31(1), 338 368. doi.org/10.1108/AAAJ-12-2014-1901

Larsson, J., \& Vinberg, S. (2010). Leadership behaviour in successful organisations: Universal or situation-dependent? Total Quality Management \& Business Excellence, 21(3), 317-334. doi.org/10.1080/14783360903561779

Macey, W.H., \& Schneider, B. (2008). The meaning of employee engagement. Industrial and Organizational Psychology, 1(1), 3-30.

Maslach, C., Schaufeli, W.B., \& Leiter, M.P. (2001). Job burnout. Annual Review of Psychology, 52, $397-422$.

McKinsey. (2021). COVID-19: Implications for business leaders. Retrieved from https://www.mckinsey.com/business-functions/risk/our-insights/covid-19-implications-forbusiness

O'Neill, K., Hodgson, S., \& Al Mazrouei, M. (2015). Employee engagement and internal communication: A United Arab Emirates study. Middle East Journal of Business, 55(2473), 1-26. 
Podsakoff, P.M., MacKenzie, S.B., Lee, J.Y., \& Podsakoff, N.P. (2003). Common Method Biases in Behavioral Research: A Critical Review of the Literature and Recommended Remedies. Journal of Applied Psychology, 88(5), 879.

Popli, S., \& Rizvi, I.A. (2016). Drivers of employee engagement: The role of leadership style. Global Business Review, 17(4), 965-979. doi.org/10.1177/0972150916645701

Raines, M.S. (2011). Engaging employees: Another step in improving safety. Professional Safety, 56(04), 36-43.

Rich, B.L., Lepine, J.A., \& Crawford, E.R. (2010). Job engagement: Antecedents and effects on job performance. Academy of Management Journal, 53(3), 617-635. doi.org/10.5465/amj.2010.51468988

Saks, A.M. (2021). Caring human resources management and employee engagement. Human Resource Management Review, 100835. doi.org/10.1016/j.hrmr.2021.100835

Scandura, T., \& Graen, G.B. (1984). Moderating effects of initial leader-member exchange status on the effects of a leadership intervention. Journal of Applied Psychology, 69(3), 428-436.

Schaufeli, W.B., Bakker, A.B., \& Salanova, M. (2006). The measurement of work engagement with a short questionnaire: A cross-national study. Educational and Psychological Measurement, 66(4), 701-716.

Schaufeli, W.B., Martínez, I.M., Pinto, A.M., Salanova, M., \& Bakker, A.B. (2002). Burnout and engagement in university students: A cross-national study. Journal of Cross-Cultural Psychology, 33(5), 464-481. doi.org/10.1177/0022022102033005003

Schneider, B., Macey, W.H., Barbera, K.M., \& Martin, N. (2009). Driving customer satisfaction and financial success through employee engagement. People and Strategy, 32(2), 22-27.

Shuck, B. (2011). Integrative Literature Review: Four Emerging Perspectives of Employee Engagement: An Integrative Literature Review. Human Resource Development Review, 10(3), 304-328. doi.org/10.1177/1534484311410840

Shuck, B., \& Herd, A.M. (2012). Employee engagement and leadership: Exploring the convergence of two frameworks and implications for leadership development in HRD. Human Resource Development Review, 11(2), 156-181. doi.org/10.1177/1534484312438211

Shuck, B., \& Reio, T.G. (2014). Employee engagement and well-being: A moderation model and implications for practice. Journal of Leadership \& Organizational Studies, 21(1), 43-58. doi.org/10.1177/1548051813494240

Shuck, B., Zigarmi, D., \& Owen, J. (2015). Psychological needs, engagement, and work intentions. European Journal of Training and Development, 39(1), 2-21. doi.org/10.1108/EJTD-08-20140061

Tensay, A.T., \& Singh, M. (2020). The nexus between HRM, employee engagement and organizational performance of federal public service organizations in Ethiopia. Heliyon, 6(6), e04094. doi.org/10.1016/j.heliyon.2020.e04094

van den Heuvel, M., Demerouti, E., Bakker, A.B., Hetland, J., \& Schaufeli, W.B. (2020). How do employees adapt to organizational change? The role of meaning-making and work engagement. The Spanish Journal of Psychology, 23(e56), 1-16. doi.org/10.1017/SJP.2020.55

Walumbwa, F.O., Avolio, B.J., Gardner, W.L., Wernsing, T.S., \& Peterson, S.J. (2008). Authentic leadership: Development and validation of a theory-based measure. Journal of Management, 34(1), 89-126. doi.org/10.1177/0149206307308913

Wang, C., \& Bird, J.J. (2011). Multi-level modeling of principal authenticity and teachers'trust and engagement. Academy of Educational Leadership Journal, 15(4), 125-147.

Wefald, A.J., Reichard, R.J., \& Serrano, S.A. (2011). Fitting engagement into a nomological network: The relationship of engagement to leadership and personality. Journal of Leadership \& Organizational Studies, 18(4), 522-537. doi.org/10.1177/1548051811404890

Wiley, J.W. (2010). The impact of effective leadership on employee engagement. Employment Relations Today, 37(2), 47-52. doi.org/doi.org/10.1002/ert.20297 
Winasis, S., Djumarno, D., Riyanto, S., \& Ariyanto, E. (2021). The effect of transformational leadership climate on employee engagement during digital transformation in Indonesian banking industry. International Journal of Data and Network Science, 5(2), 91-96. doi.org/10.5267/j.ijdns.2021.3.001

Xanthopoulou, D., Bakker, A.B., Demerouti, E., \& Schaufeli, W.B. (2009). Work engagement and financial returns: A diary study on the role of job and personal resources. Journal of Occupational and Organizational Psychology, 82(1), 183-200. doi.org/10.1348/096317908X285633

Xu, J., \& Thomas, H.C. (2011). How can leaders achieve high employee engagement? Leadership and Organization Development Journal, 32(4), 399-416. doi.org/doi.org/10.1108/01437731111134661

Yi, L., Uddin, M.A., Das, A.K., Mahmood, M., \& Sohel, S.M. (2019). Do transformational leaders engage employees in sustainable innovative work behaviour? Perspective from a developing country. Sustainability, 11(9), 2485 (2481-2418). doi.org/10.3390/su11092485

Yukl, G. (2012). Leadership in organizations (8th ed.). Prentice Hall.

Yukl, G., Gordon, A., \& Taber, T. (2002). A hierarchical taxonomy of leadership behavior: Integrating a half century of behavior research. Journal of Leadership \& Organizational Studies, 9(1), 15-32. doi.org/10.1177/107179190200900102

Yukl, G., Mahsud, R., Prussia, G., \& Hassan, S. (2019). Effectiveness of broad and specific leadership behaviors. Personnel Review, 48(3), 774-783. doi.org/10.1108/PR-03-2018-0100

Zigarmi, D., Nimon, K., Houson, D., Witt, D., \& Diehl, J. (2009). Beyond engagement: Toward a framework and operational definition for employee work passion. Human Resource Development Review, 8(3), 300-326. doi.org/10.1177/1534484309338171 